\title{
Prospect of E-Retailing In India
}

\author{
Jyoti Arora \\ Assistant Professor, Department of Public Administration, \\ Dev Samaj College for Women, Sector 45-B, Chandigarh (India)
}

\begin{abstract}
Consumer's perception regarding shopping has been changed with the introduction of internet media. Retail industry has witnessed major revolution in the changing technologyoriented business scenario of $21^{\text {st }}$ century in India. Internet has shrunk the entire World. The rules of the game in retailing are fast changing with the introduction of Information Technology. The eRetailing website is the front door of the online store that interacts between the e-retailer and consumers. The electronic retailing (e-Tailing, e-Retailing, internet retailing etc.) is the model of selling of retail goods using electronic media, in particular, the internet. E-Retailing is a subset of e-Commerce (Electronic Commerce). E-Retailing accounts for about $10 \%$ of the overall growth of $e$ Commerce market. The growth in the e-Retailing market is driven by the need to save time by urban India. It is estimated that 2.5 billion internet users, access to internet has played a significant role in growing the business markets. The Internet gives retailers an instrument for: broadening target markets, enhancing consumer relationships, extending product lines, improving cost efficiency, improving consumer communications, and delivering customized offers. Changing demographics (youthful India), changing lifestyles and exposure to the developed markets give a fillip to e-Retailing industry. One can buy anything from stereos to iPod's without stepping out through internet media. E-Retailers serve 24 hours $\mathrm{x} 7$ days in a hassle free manner to consumers. Along with advantages of e-Retailing some major issues are associated with e-Retailing such as lack of personal touch; cyber crime; bargaining is not possible and e-illiteracy among rural India. But with all, we can say that Prospect of e-Retailing market is bright in India. Consumer's cognizance; internet literacy of consumer and wider use of internet with cyber security are some of the noteworthy factors which are vital for the sustainable development and growth of e-Retailing in India.
\end{abstract}

Key Words: Consumer Satisfaction, e-Retailing, e-Tailing, Information Technology, Online Retailing,

\section{Introduction}

Modern concept of shopping is internet retailing or e-Retailing. Information Technology revolution is the incredible speed at which information is transmitted and at which technology bears down on society, constantly providing new ways of communicating, of preserving and accessing knowledge, and of tracking persons and objects. These changes have brought with them tremendous opportunities to enhance older ways of doing business.

"When a main street store builds a website, they open up opportunities to expand their market beyond geographical boundaries. The chances of losing sales from the physical shop are slight, but the potential to increase sales through their website could be enormous.....(Tiernan, B.,2000.). E-Retailers have developed many innovative promotions to lure customers and there by growing the market. As one of the market trends, e-Retailing has been widely used in retail industry and growth is increasing day by day in today's scenario. According to Turban (2006), e-Retailing is defined as retailing conducted online, over the internet. The vocabulary electronic retailing that used in internet discussions as early as 1995, the term look like an almost in evitable addition to e-mail, e-business and e-Commerce, etc. It started out way back in 1997 when Dell Computer got multimillion dollars orders on the website. E-Retailing is synonymous with business- to- consumer (B2C) transaction model of e-Commerce. eCommerce is the master field defining the e-Retailing operation. E-Commerce is a huge domain on conducting business over internet and e- Retailing is a part of it.

\section{Objective Of The Study}

1. To explore the factors that amount to the growth of e- Retailing in India.

2. To study the benefits and challenges associated with the e-Retailing business setup in brief.

3. To suggests positive recommendations for futuristic growth of e-Retailing in India. 


\section{Research Methodology}

(a) Coverage of the Study: This research paper is confined to study of Prospect of e-Retailing in India.

(b) Source of Data: The study is based on secondary data collected through various books, business magazines, journals, newspapers, internet web sites and research studies.

(c) Data Analysis: Analysis of data and information collected from published sources were made keeping the objectives of the study in mind.

\section{Essentials of e-Retailing}

There are certain essential components for an e-Retailing business to be successful. Before setting up an electronic storefront, one must consider these components well in advance.

The important essentials of e-Retailing are as:

$>$ E-Catalog

$>$ Search Engine

$>$ Shopping Cart

$>$ Distribution of Digital Goods

$>$ On line Customer sales person

$>$ An order status Checking Facility

$>$ Create Consumer Community

\section{Growth Factors Of E-Retailing In India}

As estimated by Euro-monitor report, Electronic retail growth of Indian market has already touched Rs. 2700 crores in the year 2010 from Rs. 400 crores in 2005. (http://indianecommercestory.blogspot.com/2010/01/etailing-market-in-india.html). E-Retailing, which includes purchases of durable products such as electronic items, home and kitchen appliances, as well as personal items like apparels and jeweler, constitutes 8 per cent of the overall e-commerce market in India. The broadband and mobile penetration, 3G rollout, cash on delivery, internet banking has led to rise in online transactions. Indian e-Retail market is also expected to be more than INR 10,000 crores by 2015. India has seen some dramatic changes in the way internet has affected the lives of the people.

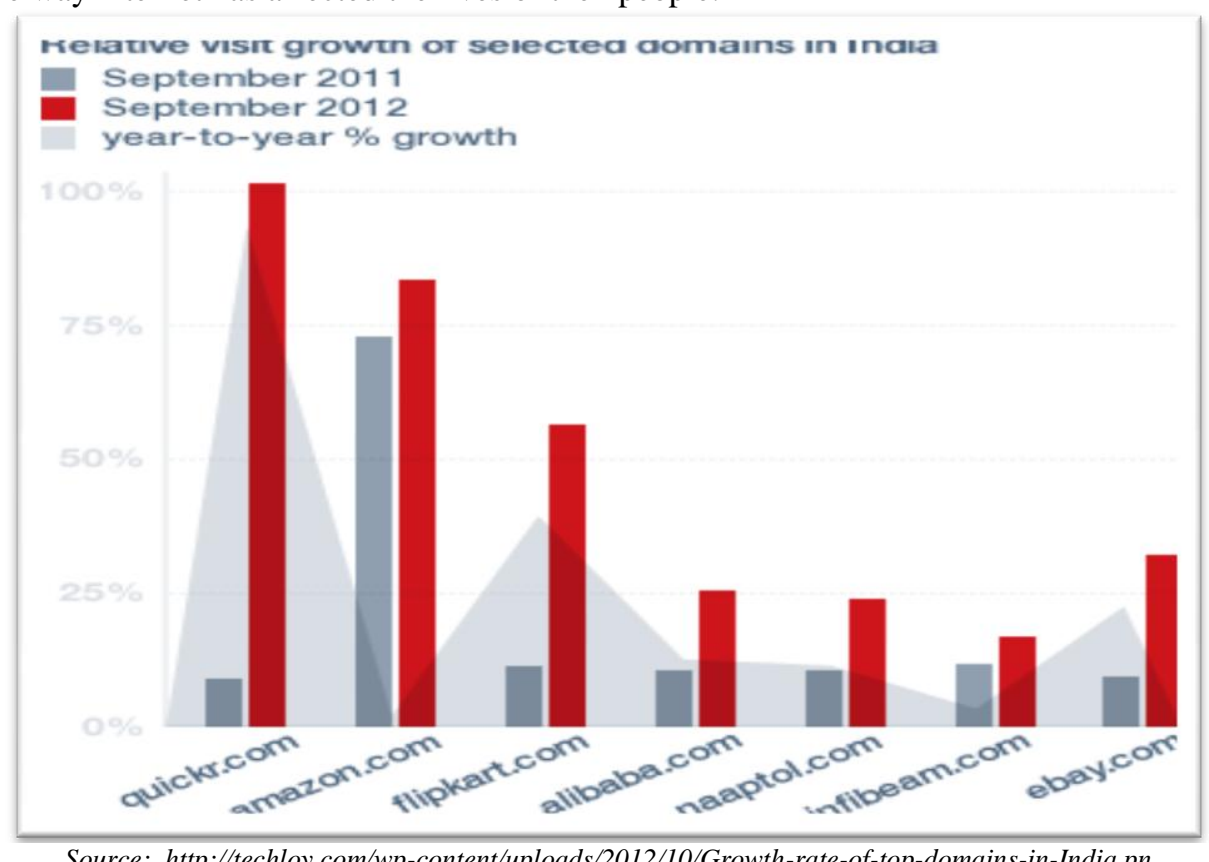

Following are the essential factors which are responsible for significant growth of e-Retailing in India.

Provision of Anywhere Anytime Services: People nowadays find it easier shopping online, as the products get home-delivered coupled with the facility to shop $24 \times 7$. Thus, an online buyer saves precious time, extra efforts and money while buying online as compared to buying from physical stores.

(a) Best Price with Better Bargains: e-Retailing eliminates the need to maintain expensive and fancy showrooms. Instead, what attracts customer attention to online stores is the 'great deals' 'best prices' and 'better bargains'. 
(b) Rising trend of cyber cities: The rising trend of internet shopping has taken off more noticeably in metropolitans such as Delhi and Mumbai where both consumers and merchants have become equally netsavvy. There is also rise in internet shopping in small cities such as Chandigarh, Ludhiana, Jalandhar, puducherry etc.

(c) Mobile Governance: Moreover the growth of the mobile communication i.e. mobile governance has led to the growth of the online retailing as people are more accessible to internet $24 \times 7$.

(d) Increased use of Net banking/credit cards/ debit cards: The electronic transactions have been made secure by the use of various technologies. The banks (RBI and others) are bringing out new guidelines (like one time passwords, security questions) so that the online transactions can be made safe for the consumer.

(e) Emergence of Nuclear Family in modern era: In the present era, nuclear families are increasing and both husband and wife are working, as they have less time to go to the market for purchasing commodities.

(f) E-Retailing attraction for NRI's : Online shopping is a big attraction for the NRIs (non-resident Indian), the apparel and gifting business online has maximum NRI consumers.

(g) Emerging Rural India: With increased internet and broadband penetration and schemes like e Choupal for the convenience of farmers, the rural India is awakening. If farmers have to purchase any such thing they have to come all the way to a nearby city. The online stores can offer them these products and many good deals in a convenient way.

(h) Mechanism of Product Comparison: Most of the websites are providing product comparison facility wherein shopper can choose the product which exactly suits him.

(i) Government-Online Initiatives: Online shopping trend is not just for consumer market. The Government is another rising user of the online buying under the overall theme of e-Commerce. A series of initiatives from the government, public sector banks and Indian Railways embracing the net, have helped to boost the confidence of users to trade online in this sector as well.

(j) Latest trend of Social Networking: In the age of $21^{\text {st }}$ Century, everyone wants to be in touch with friends and latest trends of technology by using the social networking websites.

(k) Internet Shopping Portal for e-Retailing: Internet shopping portal are also responsible for incremental growth of e-Retailing industry.

\begin{tabular}{|c|c|}
\hline e-Retailing Portals & Description \\
\hline www.amazon.com/ & $\begin{array}{l}\text { Amazon.com started as an online bookstore, but soon diversified, selling } \\
\text { DVDs, CDs, MP3 downloads, software, video games, electronics, } \\
\text { apparel, furniture, food, toys, and jewellery. Amazon.com also produces } \\
\text { consumer electronics-notably the Amazon Kindle e-book reader and } \\
\text { the Kindle Fire tablet computer-and is a major provider of cloud } \\
\text { computing services. }\end{array}$ \\
\hline$\frac{\text { www.asos.com/ }}{\text { Kingdom }}$-United & $\begin{array}{l}\text { Everybody can discover the latest in women's fashion and men's } \\
\text { clothing online. Shop from over } 40000 \text { styles, including dresses, jeans, } \\
\text { shoes and accessories from ASOS }\end{array}$ \\
\hline www.ebay.in/ & $\begin{array}{l}\text { eBay Inc. (stylized as eBay) is an American multinational internet } \\
\text { consumer-to-consumer corporation, headquartered in San Jose, } \\
\text { California. eBay. in is India's most popular online shopping mall } \\
\text { providing free online auctions for products like Mobiles/cell phones, } \\
\text { Cameras, Computers etc. }\end{array}$ \\
\hline www.futurebazaar.com/ & $\begin{array}{l}\text { It sells a variety of products including mobile phones, accessories, } \\
\text { consumer electronics, apparel, computers and general merchandise. }\end{array}$ \\
\hline www.hindustanlink.com/ & $\begin{array}{l}\text { It is a family portal of India provides services such as Beauty Care, } \\
\text { Mehendi, Free classifieds, Classified Ads, Gift Services, Shopping, } \\
\text { greetings. }\end{array}$ \\
\hline www.quikr.com & $\begin{array}{l}\text { This online portal buy and sell new \& used Mobile phones. Compare } \\
\text { prices, models ...Nokia mobile phones, Samsung Mobile phones, Ig Cell } \\
\text { phone, blackberry cell phone ads. }\end{array}$ \\
\hline wwww.Flipkart.com & $\begin{array}{l}\text { It facilitates Online Shopping of Books, Mobile Phones, Digital } \\
\text { Cameras, Laptops, Watches, Clothing \& Other Products at Best Price in } \\
\text { India. Free Shipping etc. }\end{array}$ \\
\hline
\end{tabular}




\begin{tabular}{|l|l|}
\hline www.alibaba.com/ & $\begin{array}{l}\text { On this website, find quality Manufacturers, Suppliers, Exporters, } \\
\text { Importers, Buyers, Wholesalers, Products and Trade Leads from our } \\
\text { award-winning International Trade Site. }\end{array}$ \\
\hline www.naaptol.com/ & $\begin{array}{l}\text { It provides Online Shopping in India for Cameras, Mobiles, laptops, } \\
\text { tablet, pen drive at naaptol.com, an online shopping mall | store in india. }\end{array}$ \\
\hline www.infibeam.com/ & $\begin{array}{l}\text { It is an online retailer for books, electronics, and automobiles in India. } \\
\text { Started in 2007, the company has offices in Delhi, Mumbai and } \\
\text { Bangalore, and has a total of 600 employees. In 2011, Infibeam launched } \\
\text { Buildabazaar, an e-commerce platform which allows users to create their } \\
\text { own web store. }\end{array}$ \\
\hline
\end{tabular}

Major portals are as:

\section{Major Benefits Of E-Retailing To Consumer And Retailers}

$\checkmark$ Consumer Convenience

$\checkmark$ Desirable Price and Selection

$\checkmark$ Market Research On-line interactive customer service

$\checkmark$ Promotional tool for business

$\checkmark \quad$ Virtual Showrooms bearing less cost

$\checkmark$ Better Information for Customers

$\checkmark$ 24X7X365, Anytime- Anywhere services

\section{Major Challenges Of E-Retailing In India}

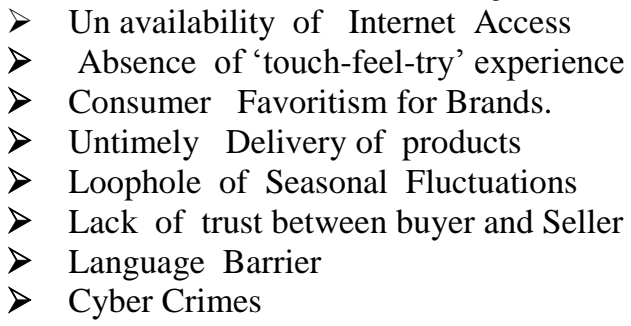

\section{Conclusions And Suggestions}

Based on the study, the following is a listing of some of the main findings and recommendations for the proposed policy agenda:

- Consumer has to be served. A best $24 \times 7 \times 365$ customer service through email, chat and toll free number facility is what the e-Retailers are providing.

- The industry/company should ensure that customer has the right information - a potent transparency weapon, right mechanism \& feels safe and secure while transacting online.

- Objective of website should be to increase public awareness and cognizance of company's name, brand, or identity and make product information available to customers and/or distributor.

- The best method to reach out to people is to create medium through blogs and discussion forums for them so that they have the freedom to rate the quality of service delivery and leave behind suggestions for improvement.

- According to consumer expectations and business needs, Managers can control the degree of freshness of web site content by making design choices, such as use of dynamic pages and the more frequent updating of content.

- Certifying and authentication authorities that have to come up as a sequel to the Information Technology (IT) Act need to be fully operational early.

- Consumer do not think twice before buying a clothing item from a trusted and tried out brand because the fit and touch is already known.

- The steps also need to be taken by sorting out the issues of security and payments. Banking laws and regulations thus need to be adjusted to the new formats and requirements so that electronic fund transfers and credit card culture evolves and sets in India.

In modern scenario, e-Retailing or online shopping has become part and parcel of the people in India. The new wave of consumerism coupled with urbanization with paradigm shifts in the demographic and psychographic dynamics have driven consumers frequently to use retail website to search for product information and make a purchase of products. And e-Retailing in India can be a success if the eRetailers change their business models and understand their consumer more because consumer are 
the real Kings. It is inevitable to create a sustainable environment mechanism for futuristic growth of e-Retailing in India.

\section{References}

[1] Vrechopoulos, A.; Siomkos, G., \& Doukidis, G. (2001): "Internet shopping adoption by Greek consumers", European Journal of Innovation Management, Vol. IV, No. 3, pp. 142-152

[2] Srinivasan, S., Anderson, R., \& Kishore, P. (2002), - Customer Loyalty in e-commerce: an Exploration of its Antecedents and Consequences, Journal of Retailing, Vol.LXXVIII, No.1, pp. 41-50.

[3] Zeithaml, V.A. (2002): "Service excellent in electronic channels", Managing Service Quality, Vol. XII, No.3, pp.135-138

[4] Wolfinbarger, M. \& Gilly, M (2003) —etailQ: Dimensionalzing, Measuring and Predicting etail Qualityll, Journal of Retailing, Vol.LXXIX, No.3, pp.183-198.

[5] Mohanty, A.K.\& Panda, J. (2008), Retailing in India: Challenges and Opportunities, The Orissa Journal of Commerce, Vol. XXIX, No.2, Bhubaneswar, July, pp. 69-79.

[6] Goswami, Shubham \& Mathur, Meera (2011), Retail goes Online- An Indian Perspective”, IJMT, Volume XIX, Number 2, July December 2011, pp. 1-11.

[7] Manish, Dwivedi; Kumawat, Mahesh \& Verma Sanjeev (2012), “Online Retailing in India : Opportunities and Challenges”, International Journal of Engineering and Management Sciences, Vol.III, No.3, December, pp.336-338

[8] [Online] Determinants of Shopper Behaviour in E-Retailing : An Empirical Analysis www.cob.unt.edu/slides/paswan/e-Retailing /India.pdf, [Accessed 1 February, 2013]

[9] [Online] E-RETAILING, www.thehindubusinessline.in/praxis/pr0301/03010440.pdf [Accessed on 1 February, 2013]

[10] [Online] etail is retail is etail, trendwatching.com/.../pdf/2012-05\%20ETAIL\%20EVOLUTION.pdf [Accessed on 2 February, 2013]

[11] [Online] Retail E-commerce - The 'Channel' Forward, www.technopak.com/.../Retail\%20E-... [Accessed on 3 February, 2013]

[12] [Online] The Indian Retail Industry , www.careratings.com/Portals/0/.../TableofContent-RetailMay2012.pd.[Accessed on 3 February, 2013].

[13] [Online] Overview of E-retailing in India, www.chillibreeze.com/articles_various/E-Retailing .asp [Accessed on 4 February, 2013]

[14] [Online]http://www.bharatook.com/market-research-reports/media-market-research-report/india-e-retail-e-Retailing marketcompanies-revenue-analysis-forecast-to-2015.html) [Accessed on 4 February, 2013]

[15] [Online] Amazon.com: Online Shopping for Electronics, Apparel, Computers ..., www.amazon.com/ [Accessed on 5 February, 2013]

[16] [Online] ASOS | Shop women's fashion \& men's clothing | Free Delivery ..., www.asos.com/ - United Kingdom [Accessed on 5 February, 2013]

[17] [Online] eBay India - Online Shopping Mall: Free Auctions, Shop/Buy/Sell ..., www.ebay.in/ [Accessed on 5 February, 2013]

[18] [Online] FutureBazaar.com - Online Shopping India 1 Buy from Home ..., www.futurebazaar.com/ [Accessed on 5 February, 2013]

[19] [Online] Hindustanlink.com: Beauty Care, Mehendi, Free Classified Ads ..., www.hindustanlink.com/ [Accessed on 5 February 2013]

[20] [Online] Mobiles|Buy Mobile|New \& Used Mobiles for Sale|Mobile ... - Quikr www.quikr.com > All Categories > Electronics \& Technology [Accessed on 5 February, 2013]

[21] [Online] Flipkart www.flipkart.com/ [Accessed on 6 February, 2013]

[22] [Online] Alibaba.com: Manufacturers, Suppliers, Exporters \& Importers from ...www.alibaba.com/[Accesed on 6 February, 2013]

[23] [Online] Naaptol, www.naaptol.com/ [Accessed on 6 February, 2013]

[24] [Online] Infibeam.com: Online Shopping for Mobiles, Books, Tablets, Gifts ... www.infibeam.com/ [Accessed on 6 February, 2013] 